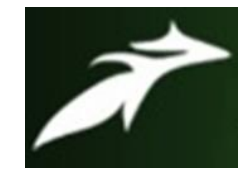

Ashok Meena et al, International Journal of Advances in Agricultural Science and Technology,

Vol.8 Issue.9, September-2021, pg. 175-182

ISSN: 2348-1358

Impact Factor: 6.057

NAAS Rating: 3.77

\title{
Constraints faced Panchayat Members in Relation to Agricultural Development Programs in Ujjain District (M.P.)
}

\author{
*Ashok Meena; **Dr. Sandhya Choudhary; ***Dr. Dhavendra Singh; Dr. S.K. Choudhary**** \\ M.Sc. Student, Agriculture Extension \& Communication, 2021 CoA, Indore* \\ Professor and Head KVK, Manawar, (M.P.)** \\ Senior Scientist (Agronomy), KVK, Manawar, (M.P.)*** \\ Chief Scientist, (Agronomy) D.A, R.P. CoA, Indore****
}

DOI: 10.47856/ijaast.2021.v08i9.019

Abstract: In india Panchayati Raj now functions as a system of governance in which Gram Panchayats are the basic units of local administration. The system has three levels: Gram Panchayat (village level), Mandal Parishad or Block Samiti or Panchayat Samiti (block level), and Zila Parishad (district level). Panchayat Raj has come to be related with two broad images. First, it is a government by itself and second it is an agency of the state government. In the integrated exercise of planning for social and economic development, coordinate roles, the present set up is a three-tier representative structure of government where the administrators, elected leaders and local population participate in the developmental effort. In this regard the members of Panchyat faced many problems there this study confront the constrains faced by members and suggestions to overcome them with 120 sample unit of Ujjain district. The major finding was obtained in this study that the most serious constraint perceived by the Gram Panchayat Members during agriculture development programmes was Insufficient use of communication media (85.83\%) as it was perceived to the highest extent by gram Panchayat Members with major suggestion of them Properly and timely use of communication media. 


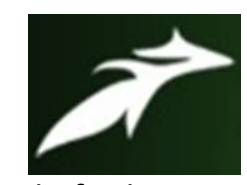

Ashok Meena et al, International Journal of Advances in Agricultural Science and Technology, Vol.8 Issue.9, September-2021, pg. 175-182

ISSN: 2348-1358

Impact Factor: 6.057

NAAS Rating: 3.77

\section{Introduction}

Information has an important role to play in all sectors of development. In the fast changing society, the role of information has become more important. Today, GPM can access information from different media like print media, electronic media etc. such as libraries, friends, colleagues, and directly from subscribed newspapers, TV channels and Internet through computers or mobiles for their rural area development. So, the importance of information cannot be denied at the village level.

The role of Panchayat Raj institutions as instruments of rural reconstruction and development needs no emphasis. They have been reorganized with wider powers and financial resources not merely as institutions of political participation but institutions of social and economic development. Panchayat Raj has come to be associated with two broad images. First, it is a government by itself and second it is an agency of the state government. In the integrated exercise of planning for social and economic development, co-ordinate roles, the present set up is a three-tier representative structure of government where the administrators, elect leaders and local population participate in the developmental effort.

The Panchayat Raj System is playing essential role in rural development. Gram Panchayat has taken the responsibility of implementing various rural development programmes of both state and central governments. The role of Panchayat Raj Institutions as instruments of rural reconstruction and development needs no emphasis. They have been reorganized with wider powers and financial resources not merely as institutions of political participation but institutions of social and economic development. Panchayat Raj has come to be associated with two broad images. First, it is a government by itself and second it is an agency of the state government. In the integrated exercise of planning for social and economic development, co-ordinate roles, the present set up is a three-tier representative structure of government where the administrators, elected leaders and local population participate in the developmental effort. The study is needed 


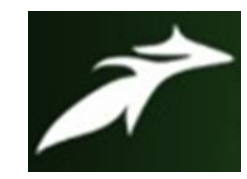

Ashok Meena et al, International Journal of Advances in Agricultural Science and Technology, Vol.8 Issue.9, September-2021, pg. 175-182

ISSN: 2348-1358

Impact Factor: 6.057

NAAS Rating: 3.77

for evaluating the role of Panchayat and the impact of the same on the development of study. Hence, "The study on role performance of elected Panchayat Members in Ujjain district of Madhya Pradesh" was undertaken with the specific objectives.

\section{Specific Objectives:}

To know the constraints encountered by the Gram Panchayat Members in performing their roles in relation to Agriculture development programmes and suggestion given to overcome them.

\section{Review literature}

Bhosale (2007) found that all the members of Gram Panchayat faced the financial problems while most of others faced the problems like lack of co-operation by other male members and lack of training.

Paul and Chakravarty (2009) observed that lack of maintenance of resource inventory, provision of funds mostly by the end of the financial year, non-availability of committed cash and kind in matching amount at the appropriate time, sub-standard quality of production inputs, inadequate availability of technical and non-technical man-power, inadequate and lack of timely availability of production inputs, lack of technical know-how, lack of viable and need oriented projects, insufficient computer facilities etc. were among the most important perceived constraints.

Pushpakumari (2012) reported that the two major problems faced by women members of Mandal Panchayat were 'Men colleagues did not allow' (81.67 per cent) and 'Social taboo' (76.67 per cent)

Deshmukh et al. (2013)observed that women Member of Gram Panchayat faced number of constraints like family male Member dominated in decision process, opposition from family member to do Gram Panchayat work while, the other problem expressed were no time to 


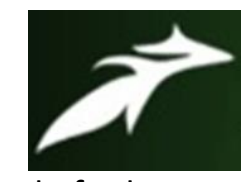

Ashok Meena et al, International Journal of Advances in Agricultural Science and Technology, Vol.8 Issue.9, September-2021, pg. 175-182

ISSN: 2348-1358

Impact Factor: 6.057

NAAS Rating: 3.77

participate in Gram Panchayat work, non-co-operation from Gram Panchayat Members, Gram Panchayat Members not obeying and the given instruction, as a women member were given less importance in Gram Panchayat, non-participation due to lack of confidence, low income of Gram Panchayat, not interested in Gram Panchayat work.

Kumari and Laxmikant (2016) found that the Members of gram Panchayat did not participate in Gram Panchayat activities due to lack of resources for development work (90.66 per cent), lack of fund on time for carrying out the work of the projects ( 88.00 per cent), lack of knowledge to the members (82.66 per cent), non-availability of persons well versed with the rural projects (80.0 per cent), lack of interest in Mukhiya for developmental works (80.0 percent), carelessness among villagers for development works (74.66 per cent) lack of education among Panchayat Members (69.33 per cent) and bribery and misappropriation of funds (54.66 per cent). The maximum number of EWVPMs considered economical constraints to be acting as the greatest hindrance in the way of their role performance ( 93.33 per cent)

\section{Material and Methods}

\section{Selection of Gram Panchayat:}

Ujjain Panchayat samiti consist of 10Gram Panchayatsnamely-Narvar, Nalwa, Talod, Matana, Chandesara, Bamora, Palkhanda, Lekoda, Gondiya and Gavandi. All these 10 Gram panchayats were taken for the study.

\section{Selection of the respondents:}

Each Gram Panchayat is constituted of with 15-20 members. Out of these 12 members were selected randomly from each Panchayat. In this manner 120members were considered as respondents for collection of data in this study. 


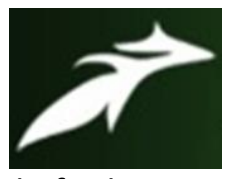

Ashok Meena et al, International Journal of Advances in Agricultural Science and Technology, Vol.8 Issue.9, September-2021, pg. 175-182

ISSN: 2348-1358

Impact Factor: 6.057

NAAS Rating: 3.77

\section{Dependent variable}

\section{Constraints faced by elected Panchayat Members in agricultural}

The statements related to role performance of Gram Panchayat Members were prepared with the help of experts \& reviews of literature. The respondents were asked to refer their role performance in agricultural development on a three point continuum viz., completely agree, agree and slightly agree. The responses of the members were recorded by 3,2 and 1 scores assigned for completely agree, agree and slightly agree respectively. By considering this, an attempt were made to categories the role performance of the respondents.

\section{Result and Discussion}

Constraints encountered by the Gram Panchayat Members in performing their roles in relation to Agriculture development programmes and suggestion given to overcome them

Table - Constraints faced by Gram Panchayat Members

$$
\mathbf{n}=\mathbf{1 2 0}
$$

\begin{tabular}{|c|c|c|c|c|}
\hline S.No. & Statement & Frequency & Percent & Rank \\
\hline 1. & $\begin{array}{l}\text { New technology is not suitable in present } \\
\text { situation }\end{array}$ & 74 & 61.67 & VII \\
\hline 2. & Lack of training & 79 & 65.83 & $\mathbf{V}$ \\
\hline 3. & Lack of finance & 76 & 63.33 & VI \\
\hline
\end{tabular}




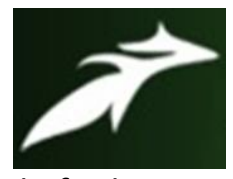

Ashok Meena et al, International Journal of Advances in Agricultural Science and Technology, Vol.8 Issue.9, September-2021, pg. 175-182

ISSN: 2348-1358

Impact Factor: 6.057

NAAS Rating: 3.77

\begin{tabular}{|c|l|c|c|c|}
\hline 4. & Farmers were not organized & 83 & 69.17 & IV \\
\hline 5. & Insufficient use of communication media & 103 & 85.83 & I \\
\hline 6. & $\begin{array}{l}\text { Unavailability of improved seeds and other } \\
\text { inputs in the village itself }\end{array}$ & 70 & 58.33 & VIII \\
\hline 7. & Short supply of electricity for irrigation & 85 & 70.83 & III \\
\hline 8. & Low support prices for cereal crops & 91 & 75.83 & II \\
\hline
\end{tabular}

It is evident from data presented in Table above that the most serious constraint perceived by the Gram Panchayat Members during agriculture development programmes was Insufficient use of communication media $(85.83 \%)$ as it was perceived to the highest extent by Gram Panchayat Members. The second most perceived constraint faced by Gram Panchayat Members during agriculture development programmes waslow support prices for cereal crops $(75.83 \%)$, Short supply of electricity for irrigation (70.83\%), farmers were not organized (69.17\%), Lack of training (65.83\%), Lack of finance $(63.33 \%)$, New technology is not suitable in present situation $(61.67 \%)$ and unavailability of improved seeds and other inputs in the village itself (58.33\%). 


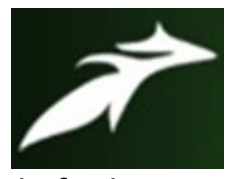

Ashok Meena et al, International Journal of Advances in Agricultural Science and Technology, Vol.8 Issue.9, September-2021, pg. 175-182

ISSN: 2348-1358

Impact Factor: 6.057

NAAS Rating: 3.77

Table 4.23 Suggestion given to overcome constraints $n=120$

\begin{tabular}{|c|c|c|c|c|}
\hline S.No. & Statement & Frequency & Percent & Rank \\
\hline 1. & $\begin{array}{l}\text { Proper guidance should be provide for new } \\
\text { technology }\end{array}$ & 63 & 52.50 & VII \\
\hline 2. & $\begin{array}{l}\text { Training programmes should be organized } \\
\text { properly }\end{array}$ & 74 & 61.66 & V \\
\hline 3. & $\begin{array}{l}\text { Financial facility should be provided at } \\
\text { different level of villages }\end{array}$ & 69 & $\mathbf{5 7 . 5 0}$ & VI \\
\hline 4. & $\begin{array}{l}\text { Farmers should make arrangement to } \\
\text { organize }\end{array}$ & 78 & 65.00 & IV \\
\hline 5. & $\begin{array}{l}\text { Properly and timely use of communication } \\
\text { media }\end{array}$ & 95 & 79.17 & I \\
\hline 6. & $\begin{array}{l}\text { Availability of improved seeds and other } \\
\text { inputs in the village itself }\end{array}$ & 55 & 45.83 & VIII \\
\hline 7. & $\begin{array}{l}\text { At least } 10 \text { hours per day supply of } \\
\text { electricity for irrigation }\end{array}$ & 81 & 67.50 & III \\
\hline 8. & Providing suitable MSP for cereal crops & 89 & 74.16 & II \\
\hline
\end{tabular}




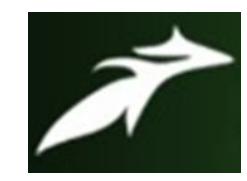

Ashok Meena et al, International Journal of Advances in Agricultural Science and Technology, Vol.8 Issue.9, September-2021, pg. 175-182

ISSN: 2348-1358

Impact Factor: 6.057

NAAS Rating: 3.77

It is evident from data presented in above table that most of the members suggest to properly and timely use of communication media (79.17\%) followed by providing suitable MSP for cereal crops (74.16), at least 10 hours per day supply of electricity for irrigation (67.50\%), farmers should make arrangement to organize (65.00\%), training programmes should be organized properly $(61.66 \%)$, financial facility should be provided at different level of villages (57.50\%), proper guidance should be provided for new technology $(52.50 \%)$ and last one was aavailability of improved seeds and other inputs in the village itself (45.83\%).

\section{Conclusion}

The most serious constraint perceived by the Gram Panchayat Members during agriculture development programmes was insufficient use of communication media $(85.83 \%)$ as it was perceived to the highest extent by gram Panchayat Members.

\section{References}

[1]. Bhosale, P.S. 2005 Leadership role in progressive and less progressive villages of marathwada. Ph.D thesis, MAU, Parbhan.

[2]. Bhosale, S.G. 2007A study of role perception and role performance of women Members in Gram Panchayat from Rahuri Taluka of Ahmednagar District. M.Sc. (Agri.) Thesis, MPKV, Rahuri.

[3]. Kumari, A. R. and Laxmikant 2016 Constraints faced by elected women village Panchayat Members in role performance. Agric. Update, 11(1).

[4]. Paul, S. and Chakravarty, R. 2009 Constraints in Role Performance of Gram Panchayat in Agriculture, Ind.Res. J. Ext. Edu. 9 (3).

[5]. Pushpakumari, C.S. 2012 Extent of participation of women Members in Mandal Panchayat activities- An exploratory study. M.Sc. (Agri.) Thesis, UAS, Bangalore. 